\title{
Negative Ion Mode Electrospray Ionization Mass Spectrometry Study of Ammonium- Counter Ion Clusters
}

\author{
N. B. Lentz and R. S. Houk \\ Ames Laboratory, United States Department of Energy, Department of Chemistry, Iowa State University, \\ Ames, Iowa, USA
}

Electrospray ionization mass spectrometry (ESI-MS) was used to examine clusters of protonated amine salt solutions with chloride counter ions in the negative ion mode. These ions have the general formula $\left[\left(\mathrm{RNH}_{3}\right)_{x} \mathrm{Cl}_{\mathrm{x}+1}\right]^{-}$. Primary amines generate a wide cluster distribution with clusters up to 14 mer for methylamine hydrochloride clusters. Secondary and quaternary amines only generate the monomer ion under identical conditions. Collision induced dissociation (CID) of the cluster ions generates cluster ions of lower $\mathrm{m} / \mathrm{z}$ with the next lower cluster being the most abundant. The product ions from $\mathrm{MeNH}_{3} \mathrm{Cl}_{2}^{-}, \mathrm{Me}_{2} \mathrm{NH}_{2} \mathrm{Cl}_{2}^{-}$and $\left(\mathrm{MeNH}_{3}\right)_{2} \mathrm{Cl}_{3}^{-}$ have low threshold appearance energies of 1.24 to $2.22 \mathrm{eV}$ center-of-mass frame. Secondary amine monomer ions have lower threshold CID energies than primary amine monomer ions. The amine threshold CID energy decreases as the carbon chain length increases. As an electrospray solvent, isopropyl alcohol (IPA) promotes the formation of counter ions and clustering. (J Am Soc Mass Spectrom 2007, 18, 285-293) (C) 2007 American Society for Mass Spectrometry

$\mathrm{E}$ SI-MS is a rapid and sensitive tool for the determination of molecules in solution [1]. Typically, the electrospray interface attempts to desolvate and remove all counter ion complexes and clusters before the ions enter the mass spectrometer. Cluster ions usually lower analyte signals, complicate mass spectra, and hinder quantification. However, there are times when cluster ions are beneficial in ESI-MS. They can be used to calibrate the $\mathrm{m} / \mathrm{z}$ scale and to study ionization mechanisms and solvent effects on the ESI process [2-6]. Cluster distributions for species such as $\mathrm{Na}_{\mathrm{x}} \mathrm{Cl}_{\mathrm{x}-1}{ }^{+}$exhibit "magic numbers" and are of interest in their own right $[7,8]$. If a molecule is poorly ionized in electrospray, counter ions can be added to increase the ionization yield $[9,10]$. The counter ions can also provide a net charge for a neutral molecule so that it can be detected in a mass spectrometer. The counter ions change the ionization properties of the molecule by changing the charge state of the molecule. If the ion originally has a net positive charge, the addition of counter ions will reduce the charge state of the ion or even convert it to the opposite polarity. If the overall charge of the ion is changed from positive to negative, negative ion mode ESI must be used. Negative ion mode has the added benefit of fewer background ions in the mass spectrum.

Published online November 7, 2006

Address reprint requests to Dr. R. S. Houk, Ames Laboratory, U.S. Department of Energy, Department of Chemistry, Iowa State University, Ames, IA 50011, USA. E-mail: rshouk@iastate.edu
Clusters can also lock in the charge state of a given ion in solution. Counter ions can interact with the ion of interest, and keep the ion in a specific charge state. Halides are commonly used because of their charge affinity and ability to coordinate around an ion [11, 12]. This charge state can be preserved by adjusting the ionization conditions at the electrospray interface.

To observe cluster ions, softer ion extraction conditions are sometimes required. This often means a lower capillary temperature and/or lower extraction voltages in the atmospheric sampling region [8].

Previous studies in our group have shown that anions such as nitrate can stabilize the oxidation state of highly charged, reactive metal ions in solution $[13,14]$. In this paper, complex and cluster ions from various amine salts are investigated by ESI-MS. CID spectra show the fragmentation pattern of the cluster ions. Threshold dissociation energies are determined for primary and secondary monomer ions as well as for a methylamine cluster ion. The threshold reactions provide valuable information regarding differences in cluster ion formation and the strength of the interaction between the cations and anions comprising the cluster.

\section{Experimental}

\section{Samples and Sample Preparation}

The amine salts and IPA were purchased from Sigma (St. Louis, MO) and used without further purification. Table 1 shows the structures of the amine salts and the 
Table 1. Chemicals, formulas, and abbreviations

\begin{tabular}{|c|c|c|}
\hline Compound name & Formula & Abbreviation \\
\hline Methylamine hydrochloride & $\mathrm{CH}_{3} \mathrm{NH}_{3}{ }^{+} \mathrm{Cl}^{-}$ & $\mathrm{MeNH}_{3} \mathrm{Cl}$ \\
\hline Ethylamine hydrochloride & $\mathrm{CH}_{3} \mathrm{CH}_{2} \mathrm{NH}_{3}{ }^{+} \mathrm{Cl}^{-}$ & $\mathrm{Et} \mathrm{NH}_{3} \mathrm{Cl}$ \\
\hline Propylamine hydrochloride & $\mathrm{CH}_{3} \mathrm{CH}_{2} \mathrm{CH}_{2} \mathrm{NH}_{3}{ }^{+} \mathrm{Cl}^{-}$ & $\mathrm{Pr} \mathrm{NH}_{3} \mathrm{Cl}$ \\
\hline Dimethylamine hydrochloride & $\left(\mathrm{CH}_{3}\right)_{2} \mathrm{NH}_{2}^{+} \mathrm{Cl}^{-}$ & $\mathrm{Me}_{2} \mathrm{NH}_{2} \mathrm{Cl}$ \\
\hline Diethylamine hydrochloride & $\left(\mathrm{CH}_{3} \mathrm{CH}_{2}\right)_{2} \mathrm{NH}_{2}{ }^{+} \mathrm{Cl}^{-}$ & $\mathrm{Et}_{2} \mathrm{NH}_{2} \mathrm{Cl}$ \\
\hline Tetraethylammonium chloride & $\left(\mathrm{CH}_{3} \mathrm{CH}_{2}\right)_{4} \mathrm{~N}^{+} \mathrm{Cl}^{-}$ & $\mathrm{Et}_{4} \mathrm{NCl}$ \\
\hline Tetrabutylammonium chloride & $\left(\mathrm{CH}_{3} \mathrm{CH}_{2} \mathrm{CH}_{2} \mathrm{CH}_{2}\right)_{4} \mathrm{~N}^{+} \mathrm{Cl}^{-}$ & $\mathrm{Bu}_{4} \mathrm{NCl}$ \\
\hline Tetrabutylammonium iodide & $\left(\mathrm{CH}_{3} \mathrm{CH}_{2} \mathrm{CH}_{2} \mathrm{CH}_{2}\right)_{4} \mathrm{~N}^{+} \mathrm{I}^{-}$ & $\mathrm{Bu}_{4} \mathrm{NI}$ \\
\hline
\end{tabular}

molecule abbreviations used in this paper. The amine salts were dissolved in a $99 \%$ isopropyl alcohol (IPA)/1\% deionized water (Millipore 18.2 M $\Omega$, Bedford, MA) solution. The final concentration of the amine salt was $1 \mathrm{mM}$. Only a stoichiometric amount of chloride was present. No extra chloride anions were added to the solution.

\section{ESI-MS (Figures 1, 2, 5, and 6)}

A triple quadrupole (QoQ) MS (TSQ-7000, Thermo Finnigan, San Jose, CA) with an on-axis electrospray source, was used. Samples were infused continuously at $5 \mu \mathrm{L} /$ min with a syringe pump (Model 22, Harvard Apparatus, Southnatic, MA). Nitrogen (80 PSI) and high-purity argon were used as the nebulizing gas and collision gas, respectively. The electrospray needle voltage was set to $-2.5 \mathrm{kV}$, and the heated capillary was kept at $250{ }^{\circ} \mathrm{C},-39.9 \mathrm{~V}$. The ring electrode and first octopole voltage were -37.4 and $+3.0 \mathrm{~V}$, respectively. The skimmer is at ground on this instrument.

\section{CID Spectra (Figures 3 and 4)}

The collision gas pressure was $0.13 \mathrm{~Pa}$ for these experiments. The collision energies (skimmer to collision cell potential offset) were 10 to $21 \mathrm{eV}$ (lab frame). The resolution of the first quadrupole was reduced to obtain higher signals in CID experiments.

\section{CID Threshold Measurements (Figures 7 and 8)}

For threshold experiments, the collision gas pressure was reduced to $0.0267 \mathrm{~Pa}$. At this pressure, the mean free path was about $25 \mathrm{~cm}$, which was longer than the octopole $(18.2 \mathrm{~cm})$. Thus, most ions passing through the collision cell experienced only one collision. The collision energy was increased from 2.5 to $26.5 \mathrm{eV}$ (lab frame) in increments of $0.2,0.3$, or $0.5 \mathrm{eV}$. Each ion of interest was monitored for $1 \mathrm{~s}$ in selected reaction monitoring (SRM) mode. Data were collected for 3 to 4 min at each collision energy and averaged.

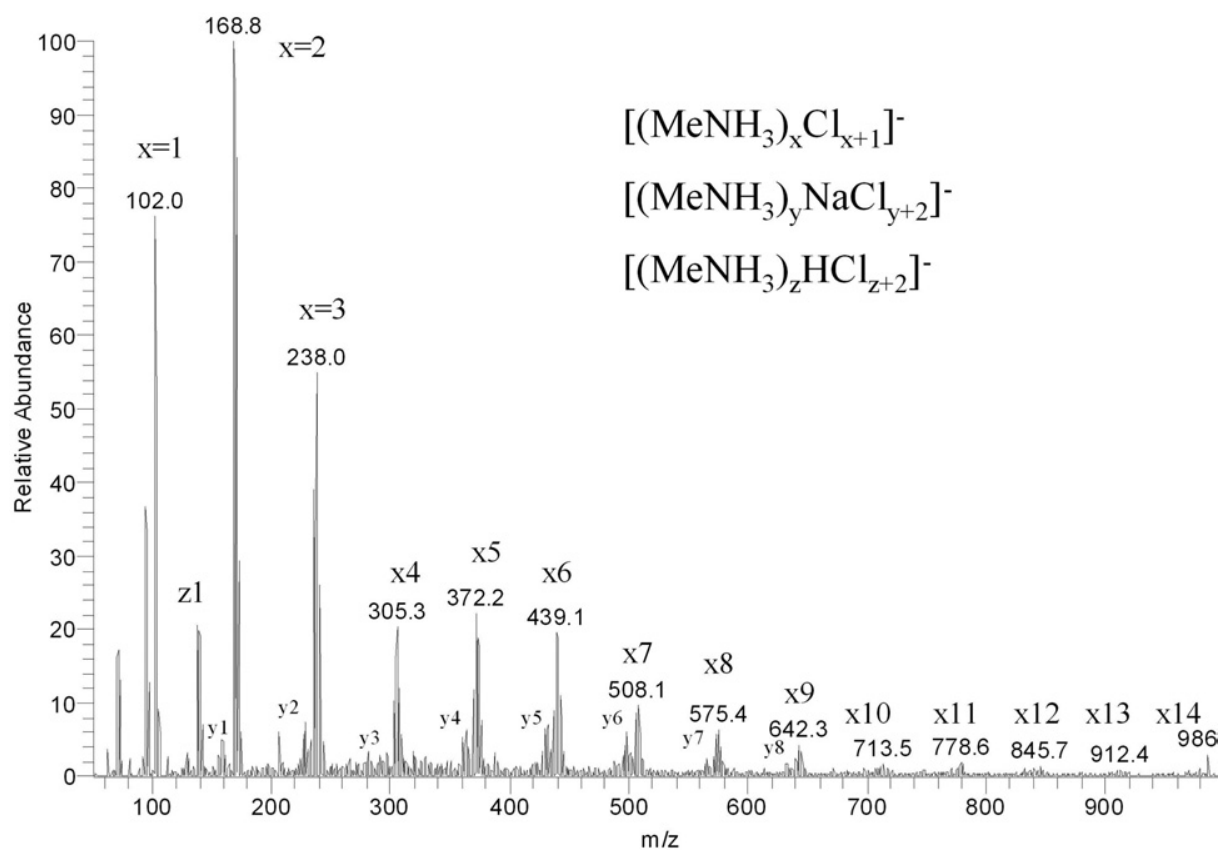

Figure 1. Mass spectrum of $1 \mathrm{mM}$ methylamine hydrochloride in $99 \%$ IPA, $1 \% \mathrm{H}_{2} \mathrm{O}$. The subscripts $\mathrm{x}, \mathrm{y}$, and $\mathrm{z}$ indicate three different cluster patterns. Clusters can be seen up to $\mathrm{x}=14$ for the main cluster pattern. 


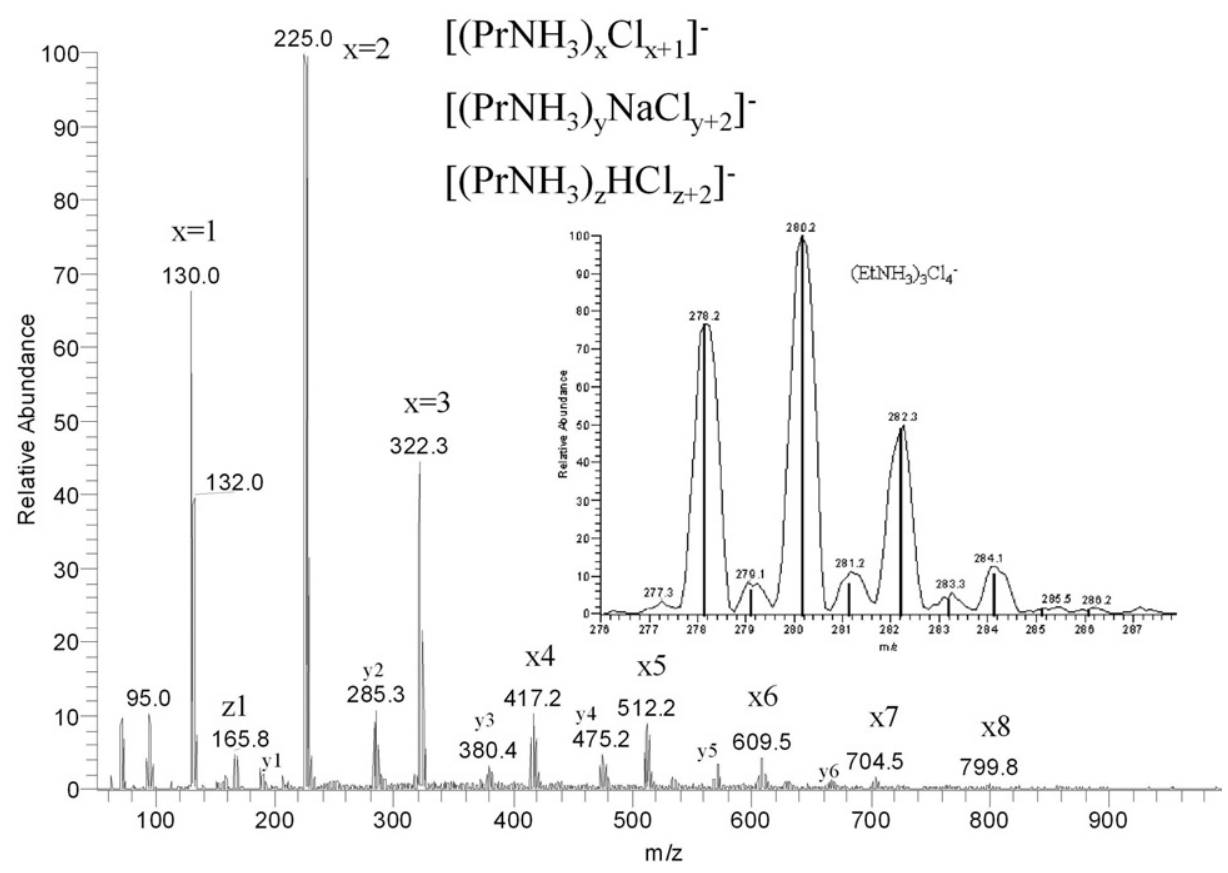

Figure 2. Mass spectrum of $1 \mathrm{mM}$ propylamine hydrochloride in $99 \% \mathrm{IPA}, 1 \% \mathrm{H}_{2} \mathrm{O}$. The cluster distribution is present up to $\mathrm{x}=8$ for the main cluster pattern. Inset shows isotope peaks for $\left(\mathrm{EtNH}_{3}\right)_{3} \mathrm{Cl}_{4}^{-}$. The black bars indicate the calculated isotope distribution for this cluster ion.

The signal intensities were converted to collision cross sections, and the collision energy was converted to ${ }^{\circ}$ the ${ }^{\circ}$ center-of-mass ${ }^{\circ}$ frame $^{\circ}{ }^{\circ}$ These $^{\circ}$ conversions $^{\circ}$ allow for accurate comparisons of the threshold energies for different ${ }^{\circ}$ ions $^{\circ}[15-17] .^{\circ}$ Armentrout ${ }^{\circ}$ provides $^{\circ}$ detailed discussions on how to convert intensities to collision cross sections, and why the center-of-mass frame must be $^{\circ}$ used $^{\circ}$ for ${ }^{\circ}$ threshold $^{\circ}$ energy $^{\circ}$ data $^{\circ}[16]^{\circ}{ }^{\circ}$ The $^{\circ}$ same methods were used in our previous article on metal nitrate ${ }^{\circ}$ complex$^{\circ}$ ions ${ }^{\circ}[13]$.

The instrument used for this experiment is not intended for accurate thermochemical measurements. For example, the kinetic energy spread of the ion beam is greater than desirable. Most analytical mass spectrometers are designed for maximum sensitivity, not accurate thermochemical measurements. However, approximate thresholds can be measured and used for general or qualitative purposes. In a previous study, the relationship between the measured and true collision energy was evaluated by using the reaction listed below:

$$
\mathrm{NO}_{3}^{-} \rightarrow \mathrm{NO}_{2}^{-}+\mathrm{O}
$$

The instrument was found to under-estimate the collision ${ }^{\circ}$ energy ${ }^{\circ}$ by $^{\circ} 0.76^{\circ} \mathrm{eV}^{\circ}[13]$.

We performed an additional threshold measurement to confirm the ion beam kinetic energy offset previously found ${ }^{\circ}[13] .{ }^{\circ}$ Sodium ${ }^{\circ}$ dichloride ${ }^{\circ}$ ions ${ }^{\circ}\left(\mathrm{NaCl}_{2}^{-}\right)$were chosen because of their similarity to the amine chloride ions investigated in this study. The $\mathrm{NaCl}_{2}^{-}$ion is comprised of only ionic interactions, like the amine clusters. $\mathrm{NO}_{3}^{-}$ is held together by covalent bonds, and the energy offset could be different for an ion comprised of only ionic interactions. The reaction

$$
\mathrm{NaCl}_{2}{ }^{-} \rightarrow \mathrm{NaCl}+\mathrm{Cl}^{-}
$$

was used to determine the kinetic energy offset of the ion beam. $\mathrm{Cl}^{-}$is the only measurable ion produced from this fragmentation reaction. The results from the threshold measurement for the dissociation of $\mathrm{NaCl}_{2}^{-}$ gave a threshold energy of $1.65 \mathrm{eV}$ (center of mass, data not shown). This measured value is $0.63 \mathrm{eV}$ lower than the ${ }^{\circ}$ computational $^{\circ}$ value $^{\circ}$ of $^{\circ} 2.277^{\circ} \mathrm{eV}^{\circ}[18]^{\circ}{ }^{\circ}$ This $^{\circ}$ offset value is similar to the $0.76 \mathrm{eV}$ offset obtained from the previous $\mathrm{NO}_{3}^{-}$threshold ${ }^{\circ}$ measurement ${ }^{\circ}[13]^{\circ}$ and ${ }^{\circ}$ confirms that the offset is not strongly dependent on the ion selected. We are more confident in the experimentallymeasured thermochemical data used previously, so 0.76 $\mathrm{eV}$ has been added to all the voltage thresholds reported below to generate "corrected" thresholds. Even if this offset is inaccurate, it is the same for all ions, and trends in the thresholds can still be compared.

\section{Results and Discussion}

\section{MS and CID of Primary Amines}

A mass spectrum of a methylamine hydrochloride solution $^{\circ}$ is ${ }^{\circ}$ shown $^{\circ}$ in $^{\circ}$ Figure $^{\circ} 1 .^{\circ}$ As $^{\circ} \mathrm{m} / z$ increases ${ }^{\circ}$ the cluster ion abundances decay in an exponential fashion, without any obvious "magic numbers," unlike those

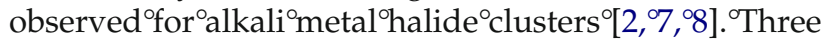
different cluster patterns are evident. The first is of the 


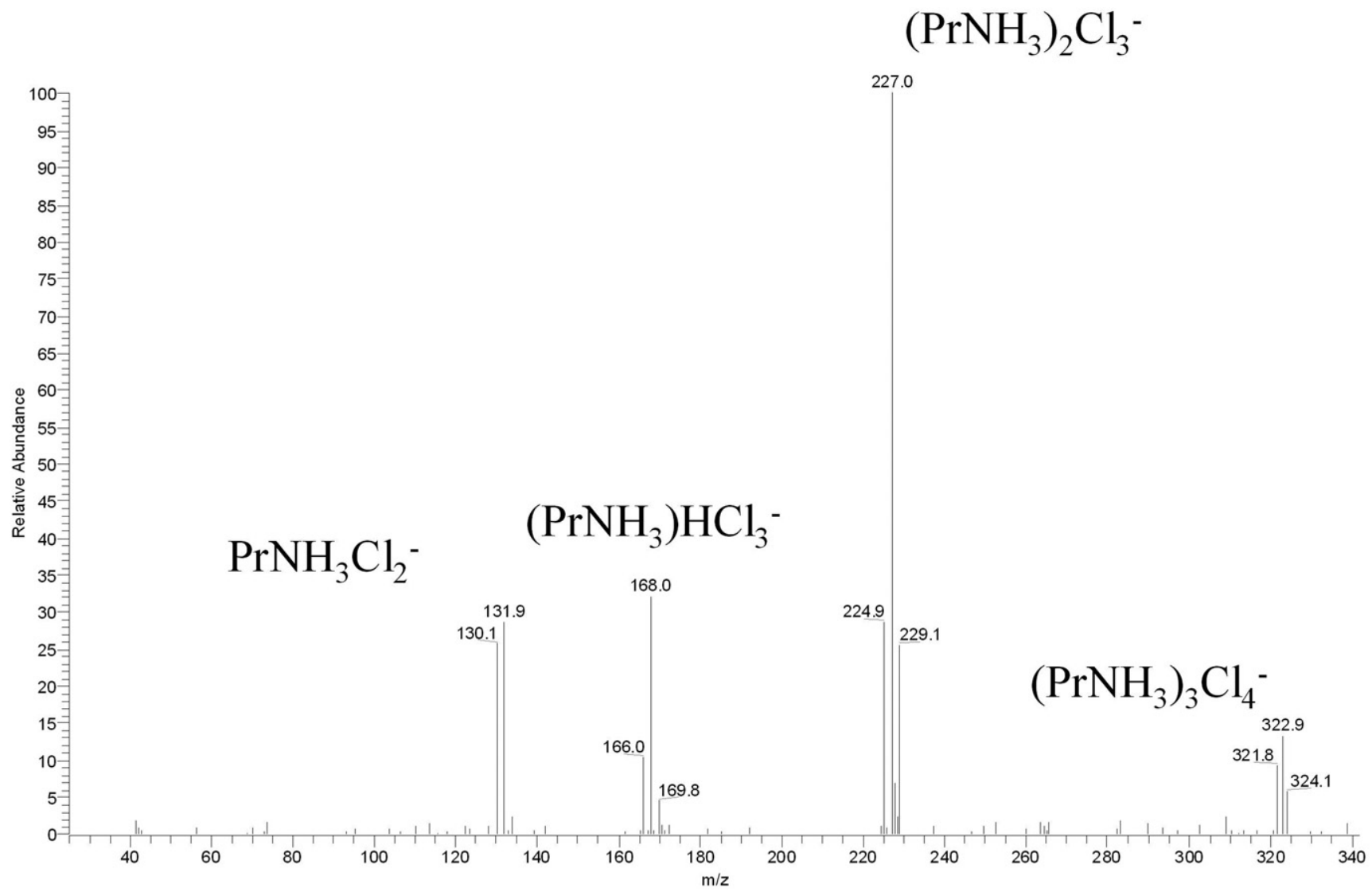

Figure 3. CID product spectrum of the $\left(\mathrm{PrNH}_{3}\right)_{3} \mathrm{Cl}_{4}^{-}$ion. The parent ion fragments into smaller cluster ions with the next smaller cluster being the most intense. Note that no $\mathrm{Cl}^{-}$ions are observed in the mass spectrum. The first mass analyzer does not transmit all the isotopomers of the parent ion equally, so the product ions do not have the expected natural isotope distribution.

form $\left[\left(\mathrm{MeNH}_{3}\right)_{x} \mathrm{Cl}_{\mathrm{x}+1}\right]^{-}$. This pattern is the most intense, and cluster ions can be seen up to $\mathrm{x}=14$.

The second cluster pattern includes one contaminant sodium ion and is of the form $\left[\left(\mathrm{MeNH}_{3}\right)_{\mathrm{y}} \mathrm{NaCl}_{\mathrm{y}+2}\right]^{-}$. The third pattern is similar to the second, except a proton replaces the sodium ion $\left[\left(\mathrm{MeNH}_{3}\right)_{z} \mathrm{HCl}_{\mathrm{z}+2}\right]^{-}$. The $\left[\left(\mathrm{MeNH}_{3}\right)_{\mathrm{y}} \mathrm{NaCl}_{\mathrm{y}+2}\right]^{-}$pattern is more prevalent, and is seen for larger clusters, than the $\left[\left(\mathrm{MeNH}_{3}\right)_{\mathrm{z}} \mathrm{HCl}_{\mathrm{z}+2}\right]^{-}$pattern. These patterns are also present in ethylamine (not shown) and propylamine, Figure ${ }^{\circ} .^{\circ}$ There $^{\circ}$ are $^{\circ}$ few $^{\circ}{ }^{\circ}{ }^{\circ}$ no $^{\circ}$ cluster $^{\circ}$ ions ${ }^{\circ}$ with ${ }^{\circ}$ more than one $\mathrm{Na}^{+}$or $\mathrm{H}^{+}$ion, unlike the numerous $\left[\left(\mathrm{MeNH}_{3}\right)_{x} \mathrm{Cl}_{\mathrm{x}+1}\right]^{-\circ}$ ions. $^{\circ} \mathrm{As}^{\circ}$ seen $^{\circ}$ in $^{\circ}$ Figures $^{\circ} 1^{\circ}$ and $^{\circ} 2$, larger clusters become less abundant as the size of the alkyl group increases.

The $^{\circ}$ inset ${ }^{\circ}$ to $^{\circ}$ Figure $^{\circ} 2^{\circ}$ compares $^{\circ}$ the ${ }^{\circ}$ calculated $^{\circ}$ and measured isotope distributions for $\left(\mathrm{EtNH}_{3}\right)_{3} \mathrm{Cl}_{4}^{-}$. In general, the observed isotope peaks agree with the calculated values to within $2 \%$ for all the ions identified in this study. When the mass range is set to include ions down to $\mathrm{m} / \mathrm{z} 30, \mathrm{Cl}^{-}$ions are seen. This observation suggests that $\mathrm{Cl}^{-}$ions are not the limiting factor in determining cluster ion formation.

A typical CID product ion spectrum is shown for $\left[\left(\mathrm{PrNH}_{3}\right)_{3}^{\circ} \mathrm{Cl}_{4}\right]^{\sigma^{\circ}}$ in $^{\circ}$ Figure $^{\circ} 3 .^{\circ} \mathrm{A}^{\circ}$ collision $^{\circ}$ cell ${ }^{\circ}$ offset voltage of $21 \mathrm{eV}$ was used to fragment the parent ion. The parent cluster ion fragments into smaller cluster ions. The next smaller cluster ion is the most intense product ion. Despite the low-resolution of the first quadrupole, it does not transmit the various isotopomers equally, especially for large clusters with multiple $\mathrm{Cl}$ atoms. Therefore, the product ions in Figures $^{\circ} 3^{\circ}$ and $^{\circ} 4^{\circ}$ often $^{\circ}$ do $^{\circ}$ not $^{\circ}$ have $^{\circ}$ the ${ }^{\circ}$ expected natural isotope distributions.

The $^{\circ}$ observed $^{\circ} \mathrm{CID}^{\circ}$ products $^{\circ}$ from ${ }^{\circ}$ Figure $^{\circ} 3^{\circ}$ are ${ }^{\circ}$ as follows:

$$
\begin{aligned}
{\left[\left(\mathrm{PrNH}_{3}\right)_{3} \mathrm{Cl}_{4}\right]^{-} \rightarrow } & {\left[\left(\mathrm{PrNH}_{3}\right)_{2} \mathrm{Cl}_{3}\right]^{-}+\mathrm{PrNH}_{3} \mathrm{Cl} } \\
& (\text { or PrNH } \\
2 & +\mathrm{HCl}) \\
\rightarrow & {\left[\left(\mathrm{PrNH}_{3}\right) \mathrm{HCl}_{3}\right]^{-}+\mathrm{PrNH}_{3} \mathrm{Cl}+\mathrm{PrNH}_{2} } \\
\rightarrow & \mathrm{PrNH}_{3} \mathrm{Cl}_{2}^{-}+2 \mathrm{PrNH}_{3} \mathrm{Cl}
\end{aligned}
$$

The species in italics are the inferred neutral products from the CID reactions. They cannot be observed because of their lack of overall charge. The reactions shown above are not meant to imply an actual mechanism, i.e., unimolecular decay of the excited parent ion. Stepwise reactions are also likely, especially because these spectra are not measured under single-collision conditions.

It is interesting to note the lack of $\mathrm{Cl}^{-}$fragment ions in $^{\circ}$ Figure $^{\circ} 3 .{ }^{\circ} \mathrm{Cl}^{-}$fragment $^{\circ}$ ions $^{\circ}$ are $^{\circ}$ not $^{\circ}$ seen $^{\circ}$ when 


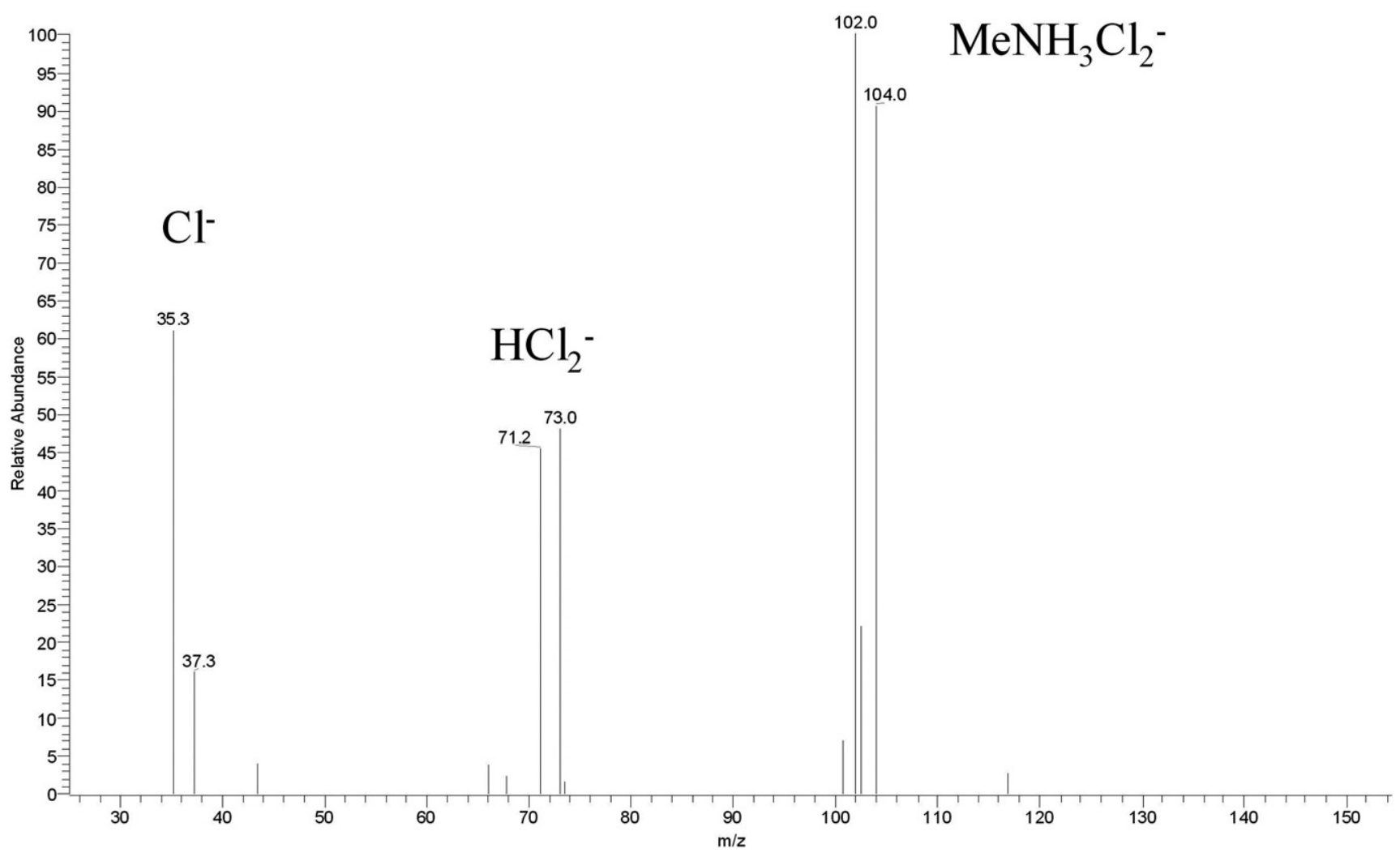

Figure 4. CID product spectrum of the $\mathrm{MeNH}_{3} \mathrm{Cl}_{2}^{-}$monomer ion, which fragments into $\mathrm{HCl}_{2}^{-}$and $\mathrm{Cl}^{-}$.

clusters larger than the monomer are fragmented. This means that not all of the $\mathrm{Cl}^{-} / \mathrm{NH}_{3}^{+}$ionic bonds are broken during CID.
Figure $^{\circ} 4^{\circ}$ shows $^{\circ} \mathrm{a}^{\circ} \mathrm{CID}^{\circ}$ spectrum ${ }^{\circ}$ of ${ }^{\circ}$ the ${ }^{\circ} \mathrm{MeNH}_{3} \mathrm{Cl}_{2}^{-}$ monomer taken with a collision energy of $15 \mathrm{eV}$ (lab); $\mathrm{HCl}_{2}^{-}$and $\mathrm{Cl}^{-}$are the only product ions present in the

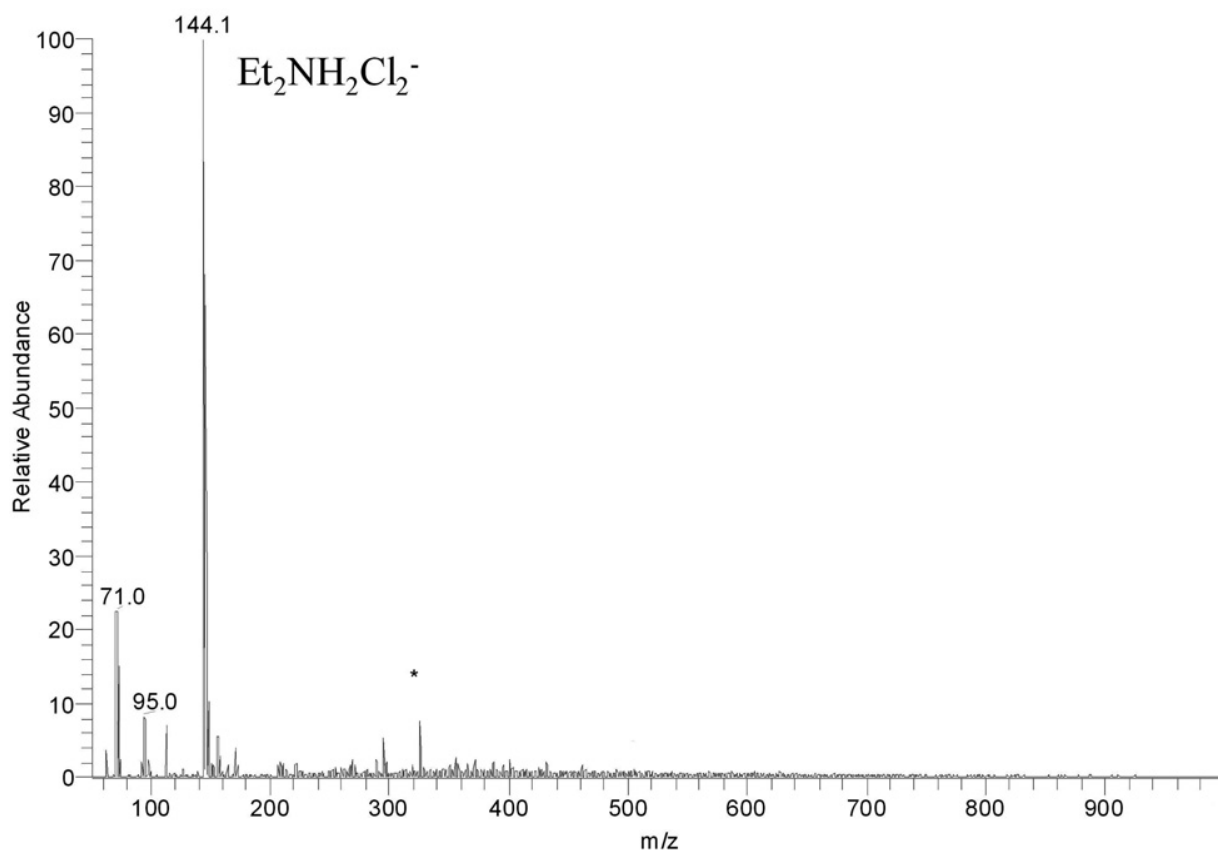

Figure 5. Mass spectrum of $1 \mathrm{mM}$ diethylamine hydrochloride in $99 \% \mathrm{IPA}, 1 \% \mathrm{H}_{2} \mathrm{O}$. The only analyte ion present is the monomer ion of $\mathrm{Et}_{2} \mathrm{NH}_{2} \mathrm{Cl}_{2}^{-}(\mathrm{m} / \mathrm{z}=144)$. The peak labeled with an asterisk is a noise spike. 


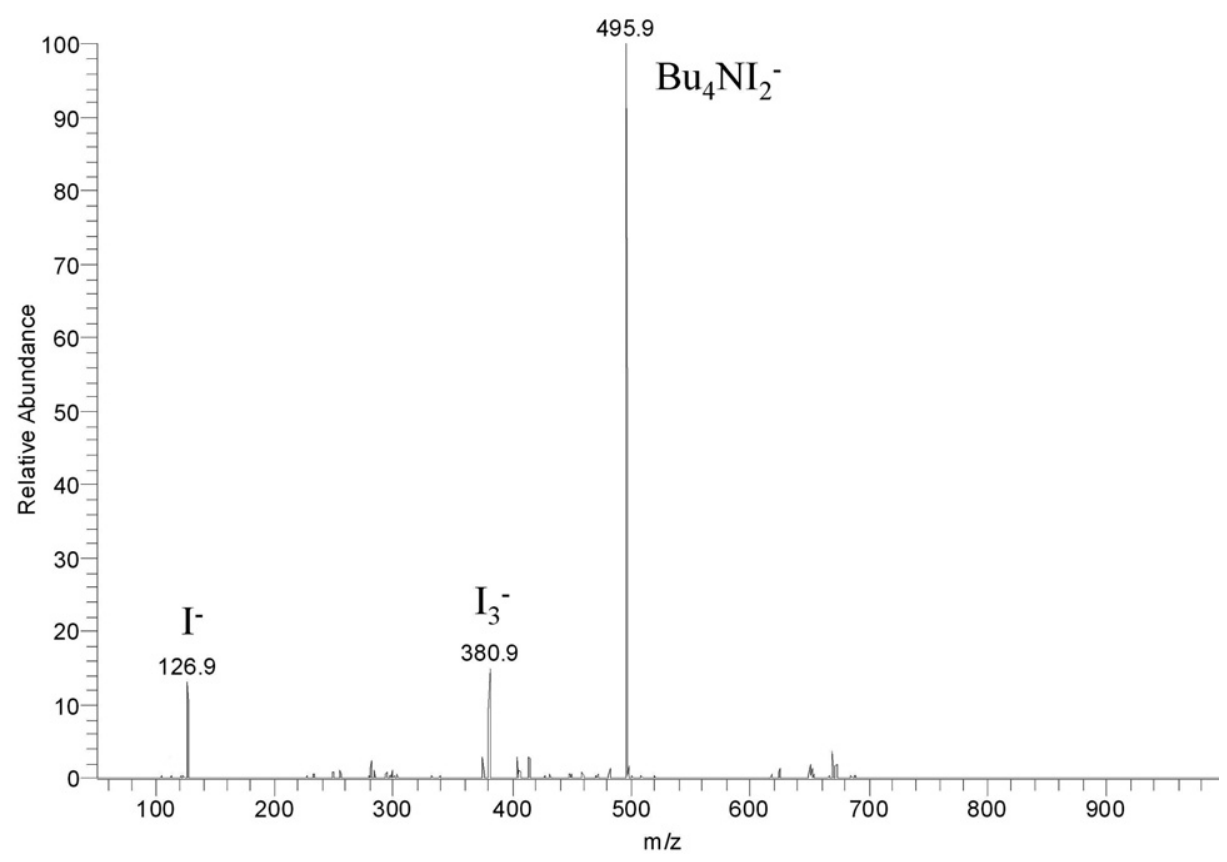

Figure 6. Mass spectrum of $1 \mathrm{mM}$ tetrabutylammonium iodide. The three ions present are $\mathrm{I}^{-}$, $\mathrm{I}_{3}^{-}$, and $\mathrm{Bu}_{4} \mathrm{NI}_{2}^{-}$.

spectrum. $\mathrm{MeNH}_{2}$ leaves as a neutral fragment and is not seen in the mass spectrum. Clearly the monomer ions behave differently than the larger cluster ions since the monomers are the only ions that yield $\mathrm{Cl}^{-}$fragment ions on CID.

\section{MS of Secondary and Quaternary Amines}

Under the same ESI conditions, higher order amines do not generate a wide cluster distribution like the primary amines. The mass spectrum for diethylamine hydro-

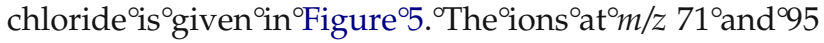
are $\mathrm{HCl}_{2}^{-}$and the chloride adduct of IPA, respectively. The only ion arising from the diethylamine is the monomer ion $\mathrm{Et}_{2} \mathrm{NH}_{2} \mathrm{Cl}_{2}^{-}$at $\mathrm{m} / z$ 144. Chloride solutions of dimethylamine and quaternary amines also yield only monomer peaks (data not shown).

Other halide anions yield similar spectra as shown for $^{\circ}$ tetrabutylammonium $^{\circ}$ iodide $^{\circ}$ in $^{\circ}$ Figure $^{\circ} 6 .^{\circ}$ Again, some free $\mathrm{I}^{-}$is observed, even though the solution contains $^{\circ}$ stoichiometrically ${ }^{\circ}$ equivalent $^{\circ}$ amounts $^{\circ}$ of $^{\circ}$ the tetrabutylammonium and iodide ions. Thus, the anion concentration is not the limiting factor in cluster ion formation for the secondary and higher amines, as noted above for the primary amines.

Our previous studies of counter anion complexes from methanol-water solutions used a large excess of nitrate $^{\circ}$ to $^{\circ}$ drive $^{\circ}$ complex $^{\circ}$ ion $^{\circ}$ formation ${ }^{\circ}[13]^{\circ} .^{\circ}$ In $^{\circ}$ our experience, large clusters are much more prevalent at lower anion concentrations in the isopropanol solvent used in the present work.

Figure $^{\circ} 6^{\circ}$ has $^{\circ}$ an $^{\circ}$ interesting ${ }^{\circ}$ peak ${ }^{\circ}$ at $^{\circ} \mathrm{m} / \mathrm{z} 381,{ }^{\circ}$ which ${ }^{\circ}$ is ascribed to ${ }^{127} \mathrm{I}_{3}^{-}$. Apparently, some of the $\mathrm{I}^{-}$is oxidized to $\mathrm{I}_{2}$ and / or $\mathrm{I}_{3}^{-}$. The high negative voltage applied to the ESI needle would drive reduction, not oxidation, so the $\mathrm{I}_{3}^{-}$is not made by electrolysis at the needle.

\section{CID Threshold Measurements}

To investigate the interaction strength of the different amine clusters, threshold measurements were performed. As mentioned earlier, the threshold results should be considered merely as approximate values, partly because of uncertainty in the correction term of $0.76 \mathrm{eV}$ added to all the measured voltages. Nevertheless, trends and general conclusions can be drawn from the measurements.

The threshold energies for the monomer ions of different primary and secondary amine clusters were examined to see if the size or number of hydrocarbon chains affected the stability of the ion. The threshold appearance energies for $\mathrm{HCl}_{2}^{-}$and $\mathrm{Cl}^{-}$from the monomer ions of methylamine $\left(\mathrm{MeNH}_{3} \mathrm{Cl}_{2}^{-}\right)$, dimethylamine $\left(\mathrm{Me}_{2} \mathrm{NH}_{2} \mathrm{Cl}_{2}^{-}\right)$, and diethylamine $\left(\mathrm{Et}_{2} \mathrm{NH}_{2} \mathrm{Cl}_{2}^{-}\right)$were monitored under the same experimental conditions. Figure $^{\circ} 7^{\circ}$ shows $^{\circ}$ typical $^{\circ}$ results $^{\circ}$ for $^{\circ}$ the ${ }^{\circ}$ threshold ${ }^{\circ}$ measurement for $\mathrm{MeNH}_{3} \mathrm{Cl}_{2}^{-}$at $\mathrm{m} / z$ 102. The corrected threshold energies are 2.06 and $2.22 \mathrm{eV}$ (center-of-mass) for $\mathrm{HCl}_{2}^{-}$and $\mathrm{Cl}^{-}$, respectively.

In $^{\circ}$ the $^{\circ}$ inset $^{\circ}$ to $^{\circ}$ Figure $^{\circ} 7,{ }^{\circ}$ the $^{\circ}$ same $^{\circ}$ experiment $^{\circ}$ is performed with the methylamine monomer ion, but without any collision gas. The cross section initially decreases, then levels off at a low value. This observation confirms that the initial signal decrease is due to instrumental conditions, and is not related to the threshold measurement of the ion. The initial decrease 


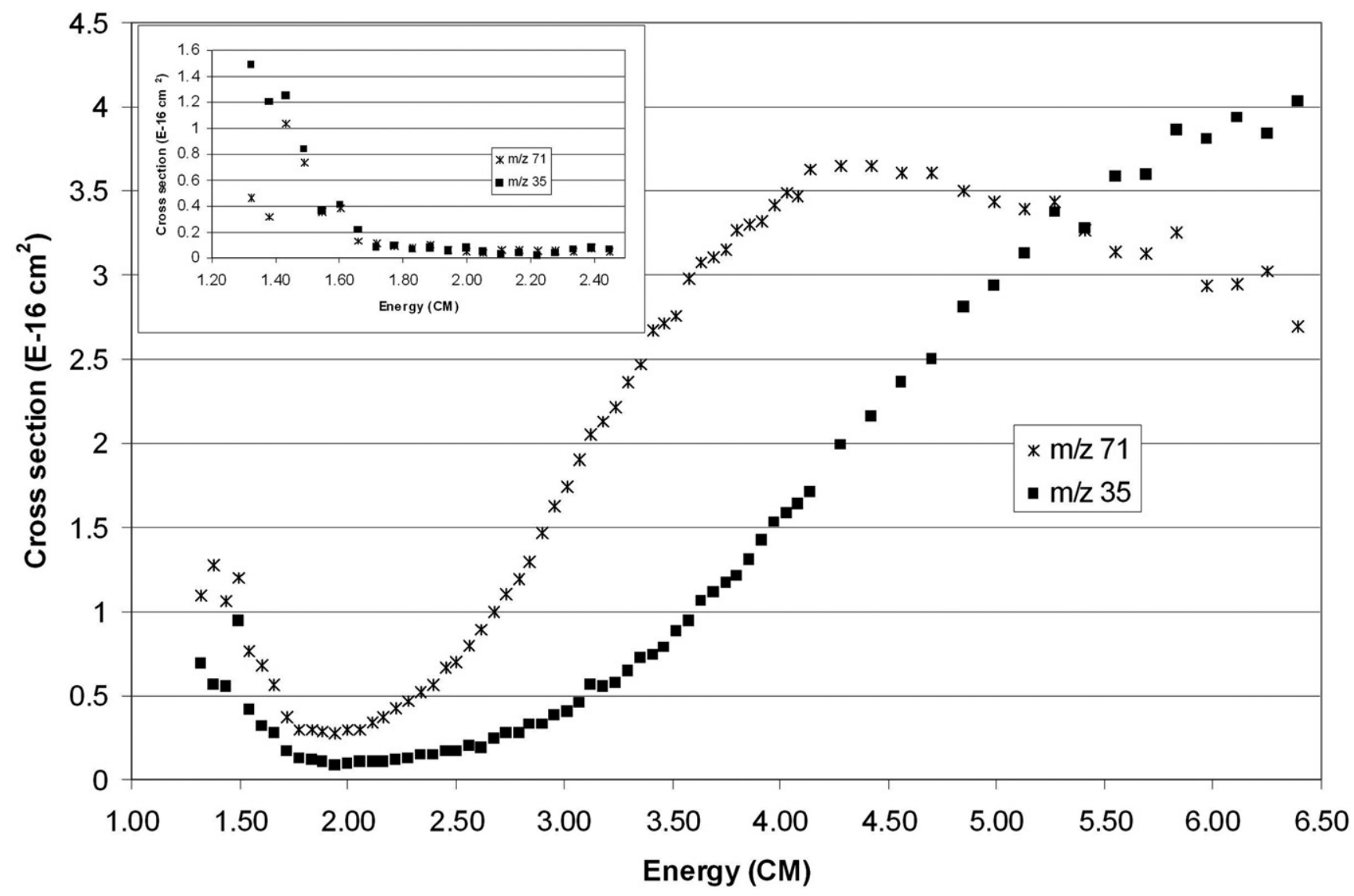

Figure 7. Measured cross sections for the production of $\mathrm{HCl}_{2}^{-}$and $\mathrm{Cl}^{-}$from $\mathrm{MeNH}_{3} \mathrm{Cl}_{2}^{-}$versus collision energy in center of mass frame. The threshold energies are 2.06 and $2.22 \mathrm{eV}$, respectively. The collision gas pressure was $0.0267 \mathrm{~Pa}$ and the data were collected in SRM mode. The threshold energies have been corrected by addition of the $0.76 \mathrm{eV}$ instrumental offset, as described in the Experimental section. Inset shows measured cross sections for $\mathrm{HCl}_{2}^{-}$and $\mathrm{Cl}^{-}$from $\mathrm{MeNH}_{3} \mathrm{Cl}_{2}^{-}$without any collision gas present in the collision cell. No apparent cross section is measured. The initial decrease is attributed to instrumental effects.

can be ignored, and the increase from the minimum is called the threshold energy.

All the measured CID thresholds are compared in Table $^{\circ} 2$. $^{\circ}$ For $^{\circ} \mathrm{CID}^{\circ}$ of ${ }^{\circ}$ the ${ }^{\circ} \mathrm{Me}_{2} \mathrm{NH}_{2} \mathrm{Cl}_{2}^{-}$monomer ion, measured threshold energies are 1.94 and $2.14 \mathrm{eV}$ (CM) for formation of $\mathrm{HCl}_{2}^{-}$and $\mathrm{Cl}^{-}$, respectively. These values are slightly lower than those for $\mathrm{MeNH}_{3} \mathrm{Cl}_{2}^{-}$. The addition of the second methyl group decreases the threshold energy, which means that the ion is less stable and requires less energy to dissociate than the cluster of the analogous primary amine. This trend is further supported by threshold measurements for $\mathrm{Et}_{2} \mathrm{NH}_{2} \mathrm{Cl}_{2}^{-}$, which produces $\mathrm{HCl}_{2}^{-}$and $\mathrm{Cl}^{-}$at 1.63 and $1.93 \mathrm{eV}(\mathrm{CM}$, Table $\left.^{\circ} 2\right) .^{\circ}$ The $^{\circ}$ monomer $^{\circ}$ ions $^{\circ}$ with $^{\circ}$ the $^{\circ}$ larger ${ }^{\circ}$ alkyl groups and more alkyl groups are less stable based upon the lower threshold energies. According to this pattern, larger cluster ions will have even lower threshold energies.

To test this theory, a threshold measurement was performed on the methylamine dimer ion $\left(\mathrm{MeNH}_{3}\right)_{2} \mathrm{Cl}_{3}^{-}$, $\mathrm{m} / \mathrm{z}$ 169. The products monitored are $\left[\left(\mathrm{MeNH}_{3}\right) \mathrm{HCl}_{3}\right]^{-}$,
$\mathrm{MeNH}_{3} \mathrm{Cl}_{2}^{-}$, and $\mathrm{HCl}_{2}^{-}$at $m / z$ 138, 102, and 71, respectively. ${ }^{\circ}$ Figure $^{\circ} 8^{\circ}$ shows $^{\circ}$ the ${ }^{\circ}$ threshold ${ }^{\circ}$ energies ${ }^{\circ}$ for $^{\circ}$ all ${ }^{\circ}$ of the product ions of $\left(\mathrm{MeNH}_{3}\right)_{2} \mathrm{Cl}_{3}^{-}$. The corrected threshold energies for $\left[\left(\mathrm{MeNH}_{3}\right) \mathrm{HCl}_{3}\right]^{-}, \mathrm{MeNH}_{3} \mathrm{Cl}_{2}^{-}$, and $\mathrm{HCl}_{2}^{-}$are very low: 1.47, 1.41, and $1.24 \mathrm{eV}(\mathrm{CM})$. This dimer ion is larger and more complex than the monomer ions, so the dimer dissociates at even lower threshold energies. The threshold energy for the production of $\mathrm{HCl}_{2}^{-}$from the dimer is much lower than the values recorded for the monomer ions. Even though the hydrocarbon chain and saturation are the same, the dimer ion is less stable.

The corrected threshold energies range from 1.24 to $2.22 \mathrm{eV}(\mathrm{CM})$. These values are reasonable for ions held together by electrostatic interactions. According to Gutsev ${ }^{\circ}{ }^{\circ}$ al. 918$],{ }^{\circ} \mathrm{CID}$ of $\mathrm{NaCl}_{2}^{-}$to $\mathrm{Cl}^{-}$takes $2.28 \mathrm{eV}$, similar to that found for the more stable ions studied in the present ${ }^{\circ}$ work. ${ }^{\circ}$ Figures ${ }^{\circ} 7^{\circ}$ and ${ }^{\circ} 8^{\circ}$ show ${ }^{\circ}$ that ${ }^{\circ}$ the instrument can distinguish the CID threshold energies for the various ions, although there could be a systematic error 


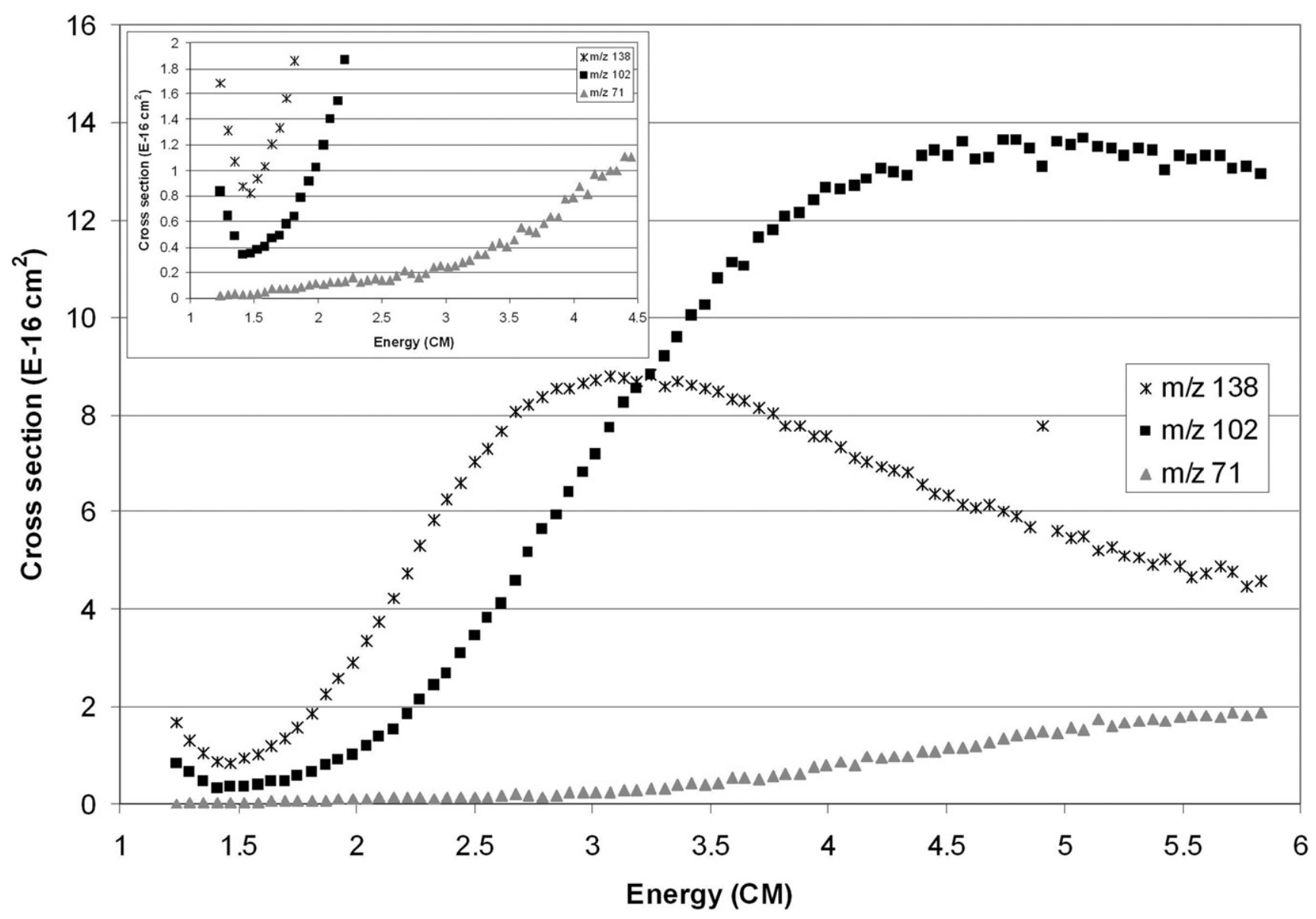

Figure 8. Measured cross sections for the production of $\left(\mathrm{MeNH}_{3}\right) \mathrm{HCl}_{2}^{-}, \mathrm{MeNH}_{3} \mathrm{Cl}_{2}^{-}$, and $\mathrm{HCl}_{2}^{-}$from $\left(\mathrm{MeNH}_{3}\right)_{2} \mathrm{Cl}_{3}^{-}$. The threshold energies are $1.47,1.41$, and $1.24 \mathrm{eV}$, respectively. Inset shows an expanded view of the threshold region.

in the measured values if the instrumental offset (see end of Experimental section) is incorrect.

\section{Conclusions}

Electrospray ionization mass spectrometry was used to evaluate the cluster ion formation capabilities of amine salts. Primary amines form many clusters, which decay off in an exponential fashion. Secondary and higher order amines produce only intense monomer peaks. This is attributed to the steric hindrance of the addi-

Table 2. Threshold appearance energies for CID product ions

\begin{tabular}{lccc}
\hline Precursor & \multicolumn{2}{c}{$\begin{array}{c}\text { Corrected appearance energy }(\mathrm{eV}) \text { of } \\
\text { indicated product ion }\end{array}$} \\
\hline \hline & $\mathrm{HCl}_{2}^{-}$ & $\mathrm{Cl}^{-}$ \\
$\mathrm{MeNH}_{3} \mathrm{Cl}_{2}^{-}$ & 2.06 & 2.22 & \\
$\mathrm{Me}_{2} \mathrm{NH}_{2} \mathrm{Cl}_{2}^{-}$ & 1.94 & 2.14 & \\
$\mathrm{Et}_{2} \mathrm{NH}_{2} \mathrm{Cl}_{2}^{-}$ & 1.63 & 1.93 & \\
& $\mathrm{HCl}_{2}^{-}$ & $\mathrm{MeNH}_{3} \mathrm{Cl}_{2}^{-}$ & $\left(\mathrm{MeNH}_{3}\right) \mathrm{HCl}_{3}^{-}$ \\
$\left(\mathrm{MeNH}_{3}\right)_{2} \mathrm{Cl}_{3}^{-}$ & 1.24 & 1.41 & 1.47 \\
\hline
\end{tabular}

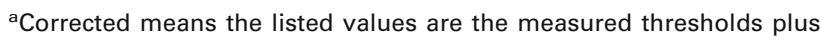
the $0.76 \mathrm{eV}$ instrumental offset. See reference [13] and the Experimental section. tional carbon chains around the charged amine. When activated by CID, the parent ion fragments into the next smaller clusters in the pattern with the next smaller cluster being the most intense. The amine molecule leaves as a neutral fragment when CID is performed on the monomer ions.

The threshold energies are low (1.2 to $2.2 \mathrm{eV})$, which is a further indication that counter ion complexation can stabilize fragile species and allow them to survive the ESI $^{\circ}$ extraction ${ }^{\circ}$ process $^{\circ}\left[13,{ }^{\circ} 14\right] .^{\circ}$ The $^{\circ} \mathrm{CID}^{\circ}$ thresholds depend on several properties of the ionic clusters. Larger alkyl groups decrease the dissociation energy. Increasing the degree of substitution from primary to secondary amines also lowers the CID threshold energy of the ion. Increasing the degree of substitution from primary to secondary amines also lowers the CID threshold energy of the ion. Perhaps the larger or more numerous carbon chains increase the distance between the opposing charges and thus weaken the electrostatic attraction. Dimer ions also exhibit lower threshold CID energies than the monomer ions. Even though the threshold energies are low, the electrostatic forces keeping the ion together are strong enough for the molecule to survive the ion extraction process, traverse through 
the mass spectrometer, and allow the ion to be detected. Currently, studies are underway to explore other interesting applications of counter ion complexes and cluster ions and their ability to provide new information regarding molecular interactions in ESI-MS.

\section{Acknowledgments}

Ames Laboratory is operated by Iowa State University for the U.S. Department of Energy, contract no. W-7405-Eng-82. This work was supported by the Chemical and Biological Sciences Program, Office of Basic Energy Sciences, Division of Chemical Sciences. The authors thank L. Huang and Bayer Company for donating the triple quadrupole instrument.

\section{References}

1. Yamashita, M.; Fenn, J. B. Electrospray Ion Source. Another Variation on the Free-Jet Theme. J. Phys. Chem. 1984, 88, 4451-4459.

2. Zhou, S.; Hamburger, M. Formation of Sodium Cluster Ions in Electrospray Mass Spectrometry. Rapid Commun. Mass Spectrom. 1996, 10, 797-800.

3. Wang, G.; Cole, R. B. Charged Residue Versus Ion Evaporation for Formation of Alkali Metal Halide Cluster Ions in ESI. Anal. Chim. Acta 2000, 406, 53-65.

4. Gamero-Castaño, M.; Fernandez-de la Mora, J. Modulations in the Abundance of Salt Clusters in Electrosprays. Anal. Chem. 2000, 72, 1426-1429.

5. Gamero-Castaño, M.; Fernandez-de la Mora, J. Mechanisms of Electrospray Ionization of Singly and Multiply Charged Salt Clusters. Anal. Chim. Acta 2000, 406, 67-91.
6. Charles, L.; Pépin, D.; Gonnet, F.; Tabet, J. Effects of Liquid Phase Composition on Salt Cluster Formation in Positive Ion Mode Electrospray Mass Spectrometry: Implications for Clustering Mechanism in Electrospray. J. Am. Soc. Mass Spectrom. 2001, 12, 1077-1084.

7. Zhang, D.; Cooks, R. G. Doubly Charged Cluster Ions $\left[(\mathrm{NaCl})_{\mathrm{m}}(\mathrm{Na})_{2}\right]^{2+}$ : Magic Numbers, Dissociation, and Structure. Int. J. Mass Spectrom. 2000 195/196, 667-684.

8. Hao, C.; March, R. E.; Croley, T. R.; Smith, J. C.; Rafferty, S. P. Electrospray Ionization Tandem Mass Spectrometric Study of Salt Cluster Ions. Part I. Investigations of Alkali Metal Chloride and Sodium Salt Cluster Ions. I. Mass Spectrom. 2001, 36, 79-96.

9. Cai, Y.; Cole, R. B. Stabilization of Anionic Adducts in Negative Ion Electrospray Mass Spectrometry. Anal. Chem. 2002, 74, 985-991.

10. Cech, N. B.; Enke, C. G. Practical Implications of Some Recent Studies in Electrospray Ionization Fundamentals. Mass Spectrom. Rev. 2001, 20, 362-387.

11. Barnett, D. Horlick, G. Quantitive Electrospray Mass Spectrometry of Halides and Halogenic Anions. J. Anal. At. Spectrom. 1997, 12, 497-501.

12. Charles, L.; Chiron, J.; Galy, J. Characterization of Ammonium Chloride Derivatives by Salt Clustering in Electrospray Ionization Mass Spectrometry. Rapid Commun. Mass Spectrom. 2003, 17, 2471-2474.

13. Li, F.; Beyers, M. A.; Houk, R. S. Tandem Mass Spectrometry of Meta Nitrate Negative Ions Produced by Electrospray Ionization. J. Am. Soc. Mass Spectrom. 2003, 14, 671-679.

14. Mollah, S.; Pris, A. D.; Johnson, S. K.; Gwizdala, A. B., III; Houk, R. S. Identification of Metal Cations, Metal Complexes, and Anions by Electrospray Mass Spectrometry in the Negative Ion Mode. Anal. Chem. 2000, 72, 985-991.

15. Armentrout, P. B. Mass Spectrometry-Not Just a Structural Tool: The Use of Guided Ion Beam Mass Spectrometry to Determine Thermochemistry. J. Am. Soc. Mass Spectrom. 2002, 13, 419-434.

16. Armentrout, P. B. Fundamentals of Ion-Molecule Chemistry. J. Anal. At. Spectrom. 2004, 19, 571-580.

17. Armentrout, P. B. Kinetic Energy Dependence of Ion-Molecule Reactions: Guided Ion Beams and Threshold Measurements. Int. J. Mass Spectrom. 2000, 200, 219-241.

18. Gutsev, G. L.; Bartlett, R. J.; Boldyrev, A. I.; Simmons, J. Adiabatic Electron Affinities of Small Superhalogens: $\mathrm{LiF}_{2}, \mathrm{LiCl}_{2}, \mathrm{NaF}_{2}$, and $\mathrm{NaCl}_{2}$. J. Chem. Phys. 1997, 107, 3867-3875. 